\title{
The Transformation of Asian Food Consumption and Russia as a Guarantor of Food Security in Asia
}

\author{
Alina Shcherbakova and Denis Shcherbakov
}

\begin{abstract}
This article examines the state of the global food problem, food security in East Asia, and the opportunity for Russia to prevent a food deficit in North Korea. The authors analyze the symptoms of the global food problem, the theoretical approaches to food security, the transformation of food consumption in Asia, and the food trade between Russia and the Korean Peninsula. One major conclusion is that Russia is in the best position among all countries to increase food exports to Asia-and especially to North Korea-as the people of Asia's food consumption habits shape the new structure of food trade between that region and the rest of the world.
\end{abstract}

Keywords global food problem, food security, food trade balance, Korean Peninsula, Russian food exports

\section{Introduction}

Nobody doubts that the food deficit is one of the major problems humanity now faces, as free access to food is among the paramount needs of every person on earth. It is no wonder, then, that this vitally important physical requirement is found at the most basic level of Abram Maslow's hierarchy of needs (Maslow 1943).

This article studies shifts in food supply and demand on the global food market and food consumption dynamics in Asia in recent decades. It also examines the connection between the food problem and food security and asks whether one country can serve as a guarantor of food security for another-or even for a region. 


\section{The Global Food Problem: The Overall Picture}

The potential food deficit is considered the world's oldest problem because it is has been the focus of discussion for two centuries. However, it appears that the price of solving the global food problem will be significantly higher in the twentyfirst century than it was before. The symptoms of the global food problem have existed for a long time. Had this phenomenon appeared only in the twenty-first century, the Food and Agriculture Organization (FAO) would not have not been founded when it was and the well-known Limits to Growth (Meadows et al. 1972) would not have been written in 1972, and so on. However, it has become clear in the early twenty-first century that food prices are rising and that a new Green Revolution is unlikely.

There are many theoretical definitions of the global food problem, but this article will use only one: the unprecedented rise of world food prices that causes starvation among the poor people of most countries (Figure 1). Former World Economic Forum Vice Chairperson Josette Sheeran gave this striking description of the global food problem: "In spite of the fact that food production is rising, there are now more starving people in the word. We put food on supermarket shelves, but the people cannot afford it" (Grain 2008, 7).

As we have already mentioned, the global food problem is not new, but two radical changes occurred in the twenty-first century: awareness of poverty has increased and signs indicate that local food crises will become more frequent (Serova 2012).

Thus, the food problem is not a question of whether our planet can provide a sufficient amount of food to feed its growing population, but whether it can

Figure 1. Food Price Index, 1960-2016

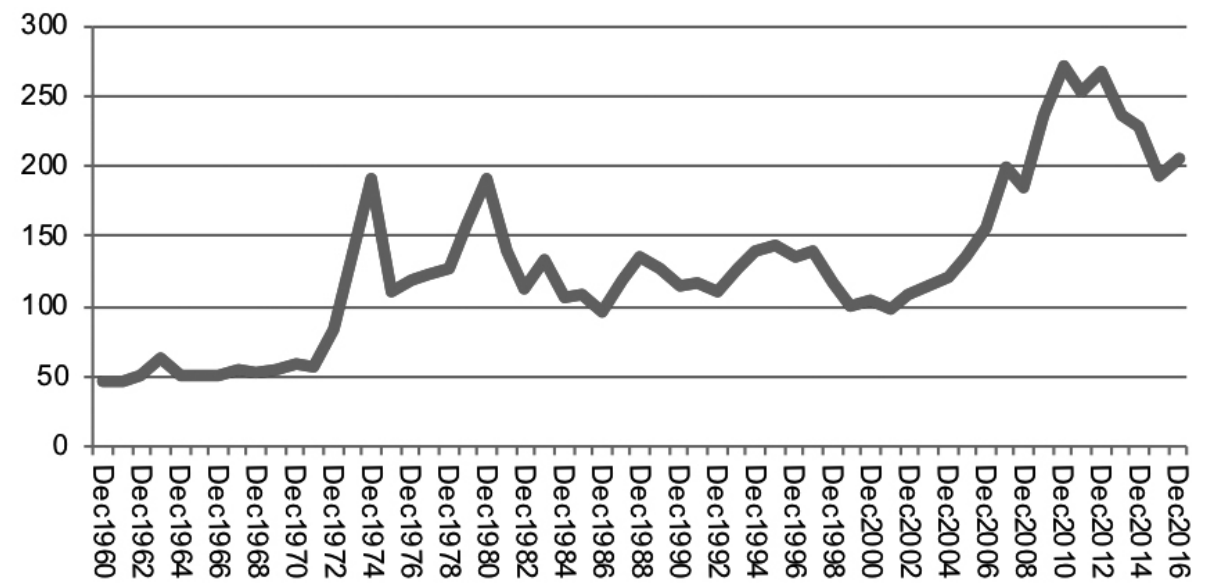

Source: UNCTAD (2017) 
produce the foods that are most needed at prices everyone can afford. The United Nations (UN) predicts that food prices will double over the next twenty years. Compared to historical trends, food commodity prices are projected to fall back to a more stable but relatively higher level (Babcock 2008).

In addition to rising prices, the second source of evidence of the global food problem is the growing food trade deficit in most regions of the world. According to the FAO, developed countries and developing countries are increasingly dependent on cereal and meat imports. Moreover, the trade deficit can be observed in developed countries. Even the United States, one of the major food exporters, overcame its food trade deficit only in the beginning of the twenty-first century (FAO 2018). Hence, most countries are dependent on the major food exporters, enabling suppliers to dominate the global food market.

Another phenomenon contributing to the global food problem is so-called "agflation" in which food prices rise faster than the price of other commodities. From 1960 until 2003, the food prices index was higher than other price indices, making food one of the major engines of global inflation (UNCTAD 2017).

The sources of the global food problem have been studied very thoroughly. They include: the increase in global population, the energy intensive nature of agricultural activity, the rising demand for biofuels, and the transformation of common consumption patterns caused by the rapid industrial development of the "Asian giants"-resulting in increases in consumption of meat in accordance with Bennett's Law. This law states that when per capita incomes rise, people begin substituting livestock foodstuffs for vegetable products (Regmi, Takeshima, and Unnevehr 2008). Thus, as Asian countries began developing rapidly, their

Figure 2. Asian Food Imports (Unit: Billion USD)

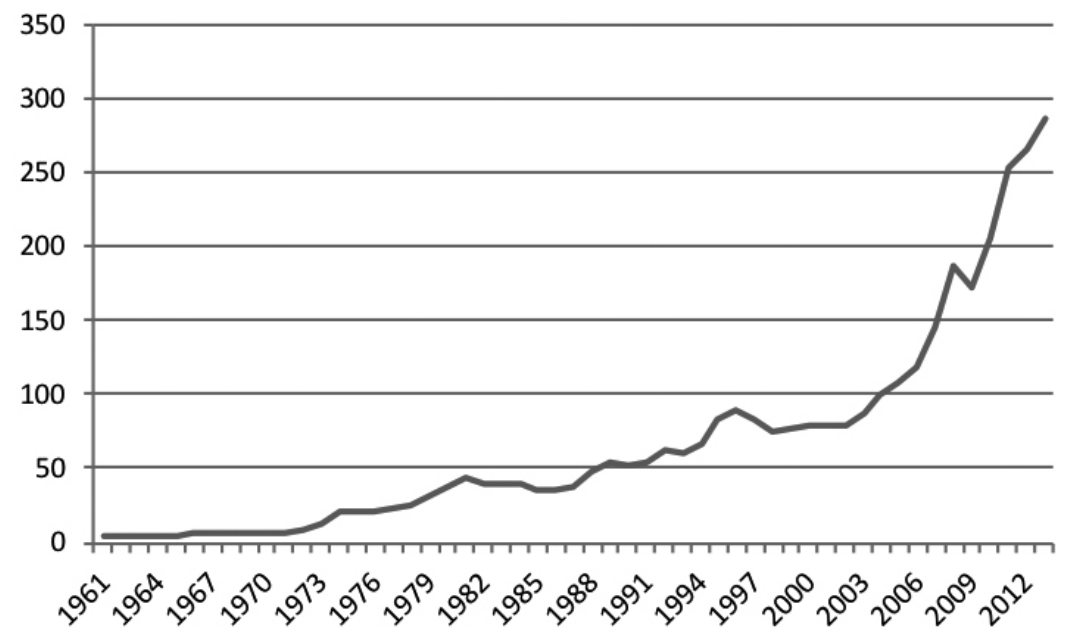

Source: FAO (2018) 
populations begin eating more meat. And to produce meat, they need more grains to feed animals. This demand for grain pushes the price of cereals higher. It is, thus, obvious that Asia will need to import an ever greater quantity of food to satisfy its population (Figure 2).

Additional contributing factors include the world's limited natural resources, climate change, and the deficit of clean water-40 percent of developing Asia is projected to face a severe water shortage by 2030 (ADB 2013,4). These problems largely stem from exogenous factors that humanity is practically powerless to change. Thus, the only way to avoid aggravating the global food problem is to acknowledge these factors and to try to reduce their impact. The global food problem is also directly connected to two other global problems: climate change and the shortage of potable water. Climate change may affect food systems in several ways. These range from directly affecting crop production, to influencing markets, food prices, and supply chain infrastructure. The relative importance of climate change for food security differs between regions. For example, climate is among the most frequently named causes of food insecurity in Asia. Certain areas of Asia where rainfall is expected to decline in the future are considered vulnerable to climate change (ibid., 21). The consequences of global climate change are less straightforward for Russia. On the one hand, higher temperatures bring certain economic advantages such as the opportunity to use the Northern Sea Route, less expensive development of mineral resources in the northern areas, and a certain improvement in the agro-climatic conditions. On the other hand, Russia might suffer negative consequences such as a growing number of natural calamities, desertification in some southern and western regions, and the possible collapse of structures built on permafrost (Likhacheva, Makarov, and Savelyeva 2010).

\section{The Global Food Problem and Food Security}

The other problem arising from the global food problem is food security and this takes on paramount importance. The FAO considers food security a global phenomenon. According to the FAO, food security exists when all people, at all times, have physical and economic access to safe and nutritious food to meet their dietary needs and food preferences for an active and healthy life. In this context, the FAO defines four aspects of food security: (1) food availability: the availability of a sufficient quantity of food of appropriate quality, supplied through domestic production or imports (including food aid); (2) food access: access by individuals to adequate resources (entitlements) for acquiring appropriate foods for a nutritious diet; (3) utilization: utilization of food through adequate diet, clean water, sanitation, and health care to reach a state of nutritional well-being in which all physiological needs are met; and (4) stability: to be food secure, a 
population, household, or individual must have access to adequate food at all times. There should be no risk of losing access to food as a consequence of sudden shocks (e.g. an economic or climatic crisis) or cyclical events (e.g. seasonal food insecurity) (FAO 2008).

In addition to international food security, there is also national food security. This can be defined in several ways. Some researchers believe that national food security presupposes a regular supply of domestic products, eliminating a given country's dependence on foreign suppliers (Kotenko 2010). Other experts contend that national food security does not mean complete self-sufficiency. In their opinion, the main criterion is that food is available for all social and economic groups of the population-and not only from domestic suppliers. The freedom to import also serves as a guarantee of national food security. Thus, we can say that the major aim of providing food security is to satisfy each person's requirements, and not only their survival needs. Each person should always have an opportunity to get any foodstuff he or she needs to satisfy his or her personal requirements. And this definition of food security shows the closest correlation to the current conditions of the world economy and policy.

The point is that, in developed countries, a new gradation of food security has recently appeared. This gradation was divided into two parts: food security of the state and food security of the population. While the first emphasizes the quantity of food, the second focuses on the quality of food and its relevance to people's needs. In this context, the question of self-sufficiency becomes pointless.

\section{The Transformation of Food Consumption in Asia}

The increasing demand for meat represents a major shift in the world food market in recent decades, radically altering its condition and structure. The increasing consumption of meat products leads to growing demand not only for meat, but also for feed, land, electricity, and other goods related to the increased production of livestock products. According to Bennett's Law, as income increases, the percentage of protein foods of animal origin in the diet increases. However, the indirect per capita consumption of cereals (grains as food + feed for cattle breeding) also grows. Thus, the growing world demand for meat entails an increasing demand for cereals and other feed plants.

Table 1 contains information about the growth of per capita caloric intake by region. It shows a 31 percent global increase in per capita caloric intake, 54 percent in Asia, and 6 percent in Oceania-indicating a strong correlation between caloric content and the income growth rate of the population.

It should be noted that the most tangible increase in the consumption of meat products is seen in Asian countries. For developed countries, the consumption of large amounts of meat per person has been the norm for many 
Table 1. Caloric Intake (Unit: kcal/person/day)

\begin{tabular}{|c|c|c|c|c|c|c|c|c|c|}
\hline \multicolumn{4}{|c|}{ World } & \multicolumn{3}{|c|}{ Africa } & \multicolumn{3}{|c|}{ North America } \\
\hline Food Item & 1961 & 2013 & $\Delta \%$ & 1961 & 2013 & $\Delta \%$ & 1961 & 2013 & $\Delta \%$ \\
\hline Cereals & 1086 & 1292 & $19 \%$ & 1062 & 1284 & $21 \%$ & 627 & 812 & $30 \%$ \\
\hline Fruits & 51 & 97 & $90 \%$ & 78 & 107 & $37 \%$ & 82 & 120 & $46 \%$ \\
\hline Oilcrops & 38 & 60 & $58 \%$ & 56 & 63 & $13 \%$ & 42 & 67 & $60 \%$ \\
\hline Sugar \& Sweeteners & 193 & 236 & $22 \%$ & 102 & 161 & $58 \%$ & 511 & 583 & $14 \%$ \\
\hline Vegetable Oils & 113 & 271 & $140 \%$ & 125 & 208 & $66 \%$ & 266 & 677 & $155 \%$ \\
\hline Vegetables & 44 & 95 & $116 \%$ & 31 & 48 & $55 \%$ & 63 & 70 & $11 \%$ \\
\hline Eggs & 18 & 36 & $100 \%$ & 4 & 9 & $125 \%$ & 66 & 55 & $-17 \%$ \\
\hline Fish, Seafood & 17 & 34 & $100 \%$ & 9 & 20 & $122 \%$ & 20 & 35 & $75 \%$ \\
\hline Meat & 110 & 237 & $115 \%$ & 67 & 90 & $34 \%$ & 331 & 417 & $26 \%$ \\
\hline Milk & 118 & 138 & $17 \%$ & 51 & 74 & $45 \%$ & 380 & 351 & $-8 \%$ \\
\hline Grand Total & 2196 & 2884 & $31 \%$ & 1993 & 2624 & $32 \%$ & 2873 & 3663 & $27 \%$ \\
\hline \multicolumn{4}{|c|}{ South America } & \multicolumn{3}{|c|}{ Asia } & \multicolumn{3}{|c|}{ Europe } \\
\hline Food Item & 1961 & 2013 & $\Delta \%$ & 1961 & 2013 & $\Delta \%$ & 1961 & 2013 & $\Delta \%$ \\
\hline Cereals & 841 & 967 & $15 \%$ & 1116 & 1422 & $27 \%$ & 1226 & 1007 & $-18 \%$ \\
\hline Fruits & 117 & 128 & $9 \%$ & 28 & 87 & $211 \%$ & 69 & 110 & $59 \%$ \\
\hline Oilcrops & 24 & 45 & $88 \%$ & 48 & 68 & $42 \%$ & 11 & 25 & $127 \%$ \\
\hline Sugar \& Sweeteners & 388 & 410 & $6 \%$ & 98 & 170 & $73 \%$ & 316 & 389 & $23 \%$ \\
\hline Vegetable Oils & 112 & 369 & $229 \%$ & 61 & 215 & $252 \%$ & 194 & 426 & $120 \%$ \\
\hline Vegetables & 28 & 39 & $39 \%$ & 43 & 119 & $177 \%$ & 53 & 80 & $51 \%$ \\
\hline Eggs & 13 & 34 & $162 \%$ & 8 & 38 & $375 \%$ & 35 & 50 & $43 \%$ \\
\hline Fish, Seafood & 9 & 18 & $100 \%$ & 15 & 37 & $147 \%$ & 27 & 47 & $74 \%$ \\
\hline Meat & 202 & 381 & $89 \%$ & 31 & 220 & $610 \%$ & 230 & 351 & $53 \%$ \\
\hline Milk & 126 & 213 & $69 \%$ & 39 & 98 & $151 \%$ & 263 & 302 & $15 \%$ \\
\hline Grand Total & 2329 & 3027 & $30 \%$ & 1805 & 2779 & $54 \%$ & 3041 & 3367 & $11 \%$ \\
\hline \multicolumn{4}{|c|}{ Oceania } & & & & & & \\
\hline Food Item & 1961 & 2013 & $\Delta \%$ & & & & & & \\
\hline Cereals & 807 & 764 & $-5 \%$ & & & & & & \\
\hline Fruits & 97 & 109 & $12 \%$ & & & & & & \\
\hline Oilcrops & 44 & 59 & $34 \%$ & & & & & & \\
\hline Sugar \& Sweeteners & 523 & 399 & $-24 \%$ & & & & & & \\
\hline Vegetable Oils & 68 & 471 & $593 \%$ & & & & & & \\
\hline Vegetables & 41 & 75 & $83 \%$ & & & & & & \\
\hline Eggs & 46 & 32 & $-30 \%$ & & & & & & \\
\hline Fish, Seafood & 21 & 45 & $114 \%$ & & & & & & \\
\hline Meat & 489 & 449 & $-8 \%$ & & & & & & \\
\hline Milk & 316 & 292 & $-8 \%$ & & & & & & \\
\hline Grand Total & 3021 & 3216 & $6 \%$ & & & & & & \\
\hline
\end{tabular}

Source: FAO (2018) 
years, so the increase will be minor. (By 2050, residents of North America and Europe will eat $89 \mathrm{~kg}$ of meat per person per year instead of $83 \mathrm{~kg}$ ). But in East and Southeast Asia, which has recently discovered affordable livestock products, the amount of meat consumed by each inhabitant will increase by $23 \mathrm{~kg}$ by 2050-nearly doubling from $28 \mathrm{~kg}$ per person per year to $51 \mathrm{~kg}$ per person per year (Institute of Development Studies 2008). Thus, demand for livestock products, primarily meat, is growing most rapidly in Asian countries.

Unlike the "Green Revolution," the meat revolution was caused by factors not from the supply side but from the demand side (Delgado et al. 1999, 1). It was caused by the growth of meat consumption in developing countries. So, from 1970 to 2000, the caloric intake of meat per person per year grew three times more in developing countries than in developed ones. Asia demonstrated the most impressive growth in meat consumption, with the number of kcal per person per day increasing six-fold between 1961 and 2013.

The fact is that, in developing countries, cereals used to be the traditional food due to low per capita income. However, cereals consumption has reached maximum saturation, whereas meat consumption in the twenty-first century will continue to grow rapidly-mainly due to increased demand in developing countries. Developed countries have already reached the maximum consumption of meat. And, because the level of meat consumption in developing countries has not yet reached the level seen in developed countries, we can expect an even more pronounced rise in the demand for meat in developing countries-and especially in Asia.

Healthcare systems in Western countries encouraged people to reduce the quantity of red meat (pork and beef) and increase the quantity of white meat (chicken and turkey) they consume. In 1983, developing countries accounted for 36 percent of meat consumption and 34 percent of milk consumption. By 1993, this share had risen to 48 percent and 41 percent respectively. In 2013, developing countries consumed 69 percent of the world's meat and 65 percent of its milk.

In countries with an average income of US $\$ 1,000$, a 1 percent increase in per capita income would lead to a 1 percent increase in pork consumption, 2 percent more chicken consumption, and more than 2 percent more beef (Schroeder, Berkley, and Schroeder 1995, 17). When the average level of per capita income exceeds US\$10,000, the increase in the consumption of meat products does not exceed 1 percent. This proves that in relatively poor countries, a slight increase in income will lead to a more significant rise in meat consumption than would a corresponding increase in rich countries. Researchers have also shown that the growth rate of meat consumption in poor countries will exceed the growth rate of household incomes.

The production of meat has shifted from developed to developing countries where the growth rate of production is significantly higher. The production of milk is still concentrated in developed countries. Cattle breeding and milk 
production are concentrated in those regions that are the main consumers of these respective products: meat is produced primarily in developed countries and Latin America, and milk in Asia where 38 percent of milk was produced in 2014. Pig breeding is most common in East and South Asia. But because of inefficient production, those regions produced less than half of the world output of meat while developing countries produced three-fourths of all cattle and two-thirds of all pigs, chicken, sheep, and geese.

According to forecasts, however, meat consumption in 2000-2020 will grow by only about 50 percent beyond its increase in 1980-2000. The reasons for this are (Delgado et al. 1999, 21): (1) because per capita meat consumption in kilograms during this period is much higher than the previous one, the absolute increase will be less; (2) there will be less growth in per capita income and a slowdown of urbanization; and (3) meat consumption will reach the saturation point.

Despite all these limiting factors, there will be a radical transformation of the consumption of meat and milk in the world. In 2020, developing countries will account for 62 percent of global meat consumption and 60 percent of all milk consumption.

According to forecasts, countries experiencing a deficit of meat will import not meat itself, but feedstuffs to produce their own meat products. Thus, the production of meat products will shift from developed countries to developing ones, and Asia will become not a net exporter of meat but a net importer.

Southeast and East Asia provide the most revealing example of Bennett's Law. There the rapid growth of per capita incomes, urbanization, and globalization have led to the replacement of traditional food products (rice and starch-bearing root crops) with meat and dairy products (as in developed countries), as well as vegetables, fruits, animal, and vegetable fats (Pingalli 2006, 281). Pingali (ibid.) called this phenomenon the "Westernization of the Asian diet." It is characterized by a predominance in the diet of wheat, fruits, and vegetables grown in temperate climates and products with high protein content. Although it is worth noting that starch-bearing root crops are still important for Asian countries, they are now used not directly as food but as feed for livestock (Fuglie 2004, 188).

Although in Europe wheat is an inferior good and is being pushed out of the consumer basket as incomes increase, in Asia the traditional rice is replaced with wheat, which becomes a priority food product. Of course, wheat in Asia is consumed in an indirect form (bread, pastries, pizza, pasta, etc.) (Pingalli 2006, 284). Thus, countries that have traditionally imported rice will shift their demand towards wheat, causing a transformation of world trade flows and the redistribution of key forces in the market. Therefore, according to the FAO (2018), whereas China accounted for 2.81 percent of total U.S. wheat exports in 1986, that figure had risen to 5.21 percent by 2013 .

Figure 3 shows the volume of imports of rice and wheat by all Asian 
Figure 3. The Import of Rice and Wheat by Asian Countries (Unit: million tonnes)

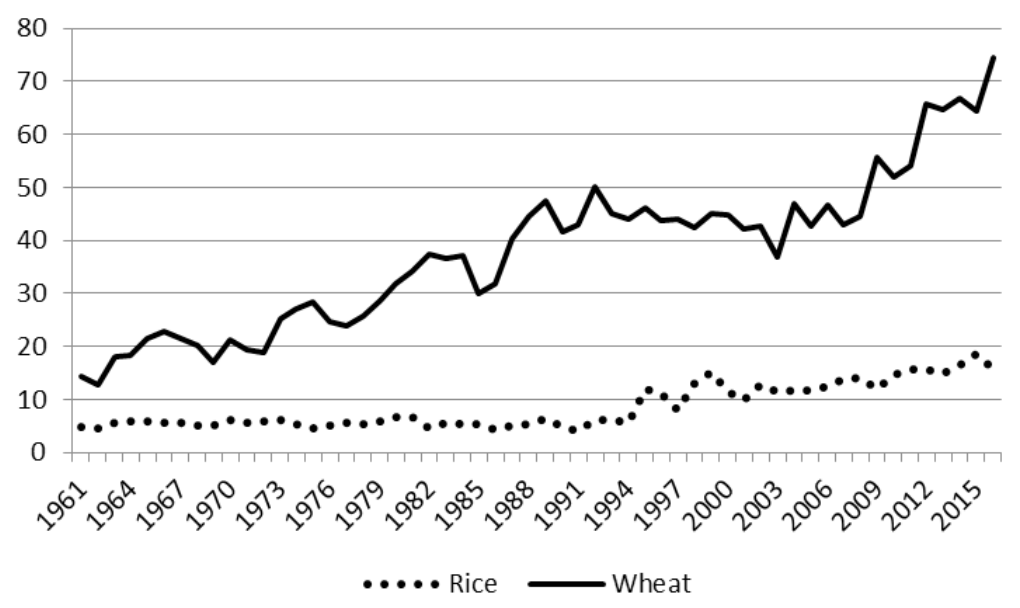

Source: FAO (2018)

countries from 1961 to 2013 . According to this data, over the past fifty years the total volume of imported rice has not grown as much as the volume of purchased wheat, and the gap between these values has increased by eighteen times.

The transformation of food consumption in Southeast and East Asian countries can be divided into two phases: the diversification of diet caused by Bennet's Law and the Westernization of the diet as a consequence of globalization. Urbanization also played a huge role, as the urban population has more access to non-traditional food products provided by large supermarkets, restaurants, etc. (Pingalli 2006, 282).

Pingalli (ibid., 283) identifies five changes in the demand for food in Southeast and East Asia: (1) a decline in per capita consumption of rice; (2) an increase in per capita consumption of wheat and commodities containing wheat; (3) an increase in the caloric content of products consumed; (4) increased consumption of temperate products; and (5) the increasing popularity of products that are easy to prepare.

Pingalli links the first of these changes to Bennett's Law, and the following four with the Westernization of Asian consumption. However, we are inclined to reconsider Pingalli's point of view and attribute the third change (an increase in the caloric content of the diet) to the consequences of Bennett's Law. We believe that the commitment to vegetable foods in a number of Asian countriesthat is often attributed to historical and cultural factors-was, in fact, caused by their populations' low level of income for a long period of time. In addition, the increase in their incomes has affected the change in diet more than has the influence of the Western culture of food consumption.

Table 2 provides data on the breakdown of crop and livestock product 
Table 2. The Balance between Crops and Livestock Products by Regions (Unit: kcal/person/day)

\begin{tabular}{|c|c|c|c|c|c|c|c|}
\hline & & 1961 & 1970 & 1980 & 1990 & 2000 & 2013 \\
\hline \multirow[t]{4}{*}{ World } & Total (kcal/person/day) & 2200 & 2398 & 2496 & 2635 & 2725 & 2884 \\
\hline & Crops & 1862 & 2032 & 2107 & 2220 & 2270 & 2051 \\
\hline & Livestock products & 338 & 366 & 389 & 415 & 455 & 411 \\
\hline & Livestock products share & $15 \%$ & $15 \%$ & $16 \%$ & $16 \%$ & $17 \%$ & $17 \%$ \\
\hline \multirow[t]{4}{*}{ Africa } & Total (kcal/person/day) & 2027 & 2130 & 2223 & 2267 & 2347 & 2455 \\
\hline & Crops & 1871 & 1964 & 2040 & 2092 & 2173 & 2269 \\
\hline & Livestock products & 156 & 167 & 184 & 175 & 174 & 186 \\
\hline & Livestock products share & $8 \%$ & $8 \%$ & $8 \%$ & $8 \%$ & $7 \%$ & $8 \%$ \\
\hline \multirow[t]{4}{*}{ North America } & Total (kcal/person/day) & 2875 & 3025 & 3165 & 3440 & 3711 & 3727 \\
\hline & Crops & 1859 & 2034 & 2194 & 2475 & 2704 & 2711 \\
\hline & Livestock products & 1016 & 990 & 971 & 965 & 1007 & 1017 \\
\hline & Livestock products share & $35 \%$ & $33 \%$ & $31 \%$ & $28 \%$ & $27 \%$ & $27 \%$ \\
\hline \multirow[t]{4}{*}{ South America } & Total (kcal/person/day) & 2304 & 2457 & 2650 & 2580 & 2782 & 2886 \\
\hline & Crops & 1890 & 2031 & 2170 & 2102 & 2174 & 2253 \\
\hline & Livestock products & 415 & 426 & 480 & 477 & 608 & 632 \\
\hline & Livestock products share & $18 \%$ & $17 \%$ & $18 \%$ & $18 \%$ & $22 \%$ & $22 \%$ \\
\hline \multirow[t]{4}{*}{ Asia } & Total (kcal/person/day) & 1805 & 2069 & 2200 & 2443 & 2606 & 2668 \\
\hline & Crops & 1695 & 1927 & 2019 & 2191 & 2244 & 2266 \\
\hline & Livestock products & 110 & 142 & 181 & 253 & 362 & 402 \\
\hline & Livestock products share & $6 \%$ & $7 \%$ & $8 \%$ & $10 \%$ & $14 \%$ & $15 \%$ \\
\hline \multirow[t]{4}{*}{ Europe } & Total (kcal/person/day) & 3050 & 3262 & 3343 & 3374 & 3249 & 3406 \\
\hline & Crops & 2285 & 2370 & 2370 & 2371 & 2348 & 2464 \\
\hline & Livestock products & 765 & 892 & 973 & 1003 & 901 & 942 \\
\hline & Livestock products share & $25 \%$ & $27 \%$ & $29 \%$ & $30 \%$ & $28 \%$ & $28 \%$ \\
\hline \multirow[t]{4}{*}{ Oceania } & Total (kcal/person/day) & 3016 & 3108 & 3027 & 3140 & 3000 & 3182 \\
\hline & Crops & 1836 & 1949 & 1988 & 2051 & 2065 & 2160 \\
\hline & Livestock products & 1180 & 1159 & 1039 & 1089 & 935 & 1022 \\
\hline & Livestock products share & $39 \%$ & $37 \%$ & $34 \%$ & $35 \%$ & $31 \%$ & $32 \%$ \\
\hline \multirow[t]{4}{*}{ China } & Total (kcal/person/day) & 1469 & 1887 & 2206 & 2612 & 2908 & 2981 \\
\hline & Crops & 1411 & 1772 & 2029 & 2299 & 2335 & 2342 \\
\hline & Livestock products & 58 & 115 & 177 & 313 & 572 & 639 \\
\hline & Livestock products share & $4 \%$ & $6 \%$ & $8 \%$ & $12 \%$ & $20 \%$ & $21 \%$ \\
\hline
\end{tabular}


consumption among the world's major population groups. The first salient feature here is the 27 percent increase in the global per capita kcal consumption from 2,200 in 1961 to 2,796 in 2013. At the same time, Asia, where we see a 48 percent increase, maintained its leading position in kcal consumption. And in China, the average intake of food energy doubled during this period.

The balance between crops and livestock products in the global population's daily food intake is an issue of particular interest. According to Table 2, the percentage of livestock products rose from 15 percent to 17 percent around the world. However, this index has remained unchanged at 7 percent for the last fifty years in Africa. We also note a decrease from 35 percent to 27 percent in North America and an increase in South America and in Europe from 18 percent to 22 percent and from 25 percent to 27 percent respectively. In Australia and Oceania, this index dropped from 39 percent to 32 percent, while in Asia it rose from 6 percent to 15 percent. The share of livestock in daily food intake grew most in China, increasing from 4 percent to 21 percent.

Unlike in developed countries, the sale of food products increases dramatically in the developing regions of the world, primarily in Asia. In 2009, for example, ninety-two multinational food trade corporations operated in Europe, eighty-four in the United States, forty-six in Asia, ten in South America, and eight in Africa. By 2015, the number of such corporations had dropped to eighty-four in Europe and eighty-two in the United States, remained constant in Africa and South America, and risen to fifty-nine in Asia (Deloitte 2017).

As multinational corporations expand, they acquire an ever wider variety of food products, thereby stimulating developing countries to add items to the market basket that had formerly been limited when local companies dominated the market.

Following the trend set by those living in developed countries, the people of developing countries now demonstrate greater loyalty to products labeled as "convenient," "natural," or "high-quality,"-although one can find the "convenience" label on 27 percent of products in Japan (a high-income state), 12 percent in Mexico (a middle-income country), and on only 6 percent in Egypt (a low-income state). This is due to the lower cost of the time required for cooking in the lowest-income states (Regmi, Takeshima, and Unnevehr 2008, iv).

The results of the research below are also quite demonstrative. One can find labels indicating good-for-health components (such as vitamins or minerals) on 51 percent of Indonesian products (a low-income country), 33 percent of Hungarian products (a middle-income country) and on just 27 percent of Japanese products (a high-income country). This is because the citizens of highincome countries a priori believe that the products they buy contain healthy ingredients and focus more carefully on the absence of noxious impurities and chemical additives (ibid.). 


\section{Food Security of the Korean Peninsula}

The growth of food prices in Asia in the early twenty-first century reflects the confluence of a number of factors: urbanization and rising prosperity-both of which bring more diversified food demands; a tighter linkage between food, energy, and financial markets; adverse weather; declining growth in agricultural productivity; and, during the peak of the crisis, ill-advised policy reactions by major food exporting and importing countries (ADB 2013, 11).

As a result of a growth in crops, livestock, and fisheries production over the past two decades, the FAO estimates that average dietary energy supply adequacy increased by about 20 percent in East and Southeast Asia. Because of this growth, only one country in the region, North Korea, now has total food supplies inadequate to meet people's average dietary needs. Thus, the prevalence of stunted physical development remains high in North Korea (32 percent) (FAO 2015, 18).

Russia has provided millions of dollars worth of food aid to North Korea in recent years, including nearly half of the country's grain imports (50 mln tonnes) (ibid.; Toloraya 2014).

The major part of Russian exports to North Korea in the first quarter of 2015 consisted of the following product types (Mishin 2016):

- mineral fuels, mineral oils and products of their distillation; bituminous substances; mineral waxes ( 90.8 percent)

- fish and crustaceans, mollusks and other aquatic invertebrates (3.9 percent)

- wood and articles of wood; wood charcoal (2.7 percent)

- oil seeds and oleaginous fruits; miscellaneous grains, seeds, and fruit; industrial or medicinal plants; straw and fodder ( 0.5 percent)

- furniture; bedding, mattresses, mattress supports, cushions and similar stuffed furnishings; lamps and lighting fittings, not elsewhere specified or included; illuminated signs, illuminated nameplates and the like; prefabricated buildings ( 0.4 percent)

- sugars and sugar confectionery (0.4 percent)

- products of the milling industry; malt; starches; inulin; wheat gluten (0.2 percent)

- man-made staple fibers (0.2 percent)

Russia is becoming a very important food trade partner for the Korean Peninsula. The table below shows that the quantity of food imported from Russia has been growing over the last twenty years (with the exception of the last two years).

The recent decline can be explained by the consequences of the "Ukrainian crisis" that have affected the old international trade system and aggravated the transformation of the global food market. The United States, Canada, Australia, Norway, and the European Union (EU) imposed several sanctions on the Russian economy. Russia responded by banning food imports from those countries. 
Table 3. Russian Food Exports to the Korean Peninsula (Units: Million USD)

\begin{tabular}{l|c|c|c|c|c}
\hline \multicolumn{1}{c|}{ Year } & 1996 & 2000 & 2005 & 2009 & 2015 \\
\hline Peninsula total & 203.59 & 122.69 & 276,57 & 456.93 & 866,54 \\
\hline North Korea & 0.54 & 0.04 & 0.01 & 6.08 & 10.46 \\
\hline South Korea & 203.05 & 122.65 & 276.56 & 450.85 & 856.07 \\
\hline
\end{tabular}

Source: Calculated by authors on the basis of data from UNCTAD (2017)

Because Russia was highly dependent on food imports from the United States, Europe, and Australia, and imported those foodstuffs in the most logistically efficient way, when the sanctions were imposed there were only two ways of coping with the problem: by increasing domestic production (a lengthy process), or substituting those foods with more expensive imports from other countries.

Relatively few foods have been included in the Russian countersanctions. Of those, 14.7 percent are fruits and vegetables and 13.3 percent are fish. Chicken meat accounts for only 7.9 percent, but actual dependency is higher because Russia continues to import hatchable eggs. The situation with beef is also not overly alarming; Russia had imported only 7.4 percent of its beef from "sanctioned" countries. Furthermore, beef is a luxury product in Russia, so consumers are willing to pay more for it. Pork is more prevalent in the Russian diet, and the country imports only 13.2 percent of this product. The situation is more critical with cheese, for which Russia had depended on the EU and other "sanctioned" countries for 33 percent of its supply (Savelyeva 2014). Thanks to the re-export of these foodstuffs through Belarus, price increases have remained moderate, but this state of affairs cannot last forever. Russia is highly dependent on imports of processed foods, so-called "niche products" such as sausage and other specialized meat products.

Thus, sanctions have highlighted those sectors that can and should be priorities for increasing domestic production and caused a reexamination of methods for stimulating domestic agricultural production. In particular, state financing now includes new branches devoted to re-establishing Russian breeding and genetics programs.

The Russian government is also expanding a new state program to ensure that domestic agricultural products remain competitive on the internal and global markets even after sanctions are lifted. Thus, although exports to the two Koreas increased continuously, Russia responded to Western sanctions by decreasing its overall food exports to mitigate rising domestic food prices.

Although the share of agricultural products that Russia exported to North Korea fell from 10.2 percent in 2015 to 9.4 percent in 2016, there were several important changes in the quantities of exported foodstuffs. Flour-and-cereals industry products rose by 47 percent and vegetable oils and fats by 437 percent, 
while the export value of cereals fell by a dramatic 90 percent (Russian Foreign Trade 2017).

It is also worth noting that among Russian exports to North Korea, food is second only to mineral resources, which account for a 57 percent share (Federal Customs Service of Russia 2017). Unfortunately, UN sanctions imposed against North Korea in 2017 limited Russia's ability to export food to that country. However, those restrictions are not expected to last long.

\section{Conclusion}

With its huge potential for developing agricultural exports and its other advantages, Russia can play a major role in providing food security in North Korea. In a world suffering from shortages of both arable land and clean water, Russia is rich in both. Russia holds 20 percent of the world's water resources along with 3.3 percent of its farmland and 9 percent of its arable land. At present, however, more than 30 million hectares of Russian farmland are not utilized fully (Likhacheva, Makarov, and Savelyeva 2010).

Ironically, Russia benefits from climate change because warming temperatures enlarge the areas suitable for growing basic crops and make possible the introduction of new and more productive plant varieties. This increases the gross yield of crops. In addition, Russia's logistical cost of exporting food to North Korea is very low due to the geographic proximity of the two countries.

The unique combination of these advantages makes it clear that Russia is uniquely positioned to increase food exports to Asia, and especially to North Korea-a country where land and potable water are scarce. An increase in Russian exports would also help answer North Korea's growing demand for food. Thus, food should account for a greater share of Russian-North Korean trade, creating a win-win situation in which North Korea achieves greater food security and Russia diversifies its exports to mitigate its dependency on fossil fuel exports.

\section{Acknowledgments}

This research was supported by the grant of the Faculty of World Economy and International Affairs of National Research University Higher School of Economics.

\section{References}

ADB (Asian Development Bank). 2013. "Food Security Challenges in Asia.” Working 
Paper, October. https://www.oecd.org/derec/adb/Food-security-challenges-Asia.pdf (accessed October 15, 2018).

Babcock, Bruce A. 2008. "Charting Growth in Food Demand." Iowa Ag Review Online 14 (3). https://www.card.iastate.edu/iowa_ag_review/summer_08/article4.aspx (accessed October 15, 2018).

Delgado, Christopher, Mark Rosegrant, Henning Steinfeld, Simeon Ehui, and Claude Courbois. 1999. "Livestock to 2020: The Next Food Revolution." International Food Policy Research Institute, FAO, and International Livestock Research Institute, May. http://www.fao.org/ag/againfo/resources/documents/lvst2020/20201.pdf (accessed October 15, 2018).

Deloitte. 2017. "Global Powers of Retailing 2017: The Art and Science of Customers." https://www2.deloitte.com/content/dam/Deloitte/global/Documents/consumerindustrial-products/gx-cip-2017-global-powers-of-retailing.pdf (accessed October $15,2018)$.

FAO (Food and Agriculture Organization). 2008. "An Introduction to the Basic Concepts of Food Security." http://www.fao.org/docrep/013/al936e/al936e00.pdf (accessed January 12, 2018).

FAO (Food and Agriculture Organization). 2015. "Regional Overview of Food Insecurity: Asia and the Pacific." http://www.fao.org/3/a-i4624e.pdf (accessed October 15, 2018).

FAO (Food and Agriculture Organization). 2018. "FAOSTAT." Accessed January 12. http:// faostat.fao.org/.

Federal Customs Service of Russia Statistics. 2017. "Foreign trade of Russia with the key countries, January-August 2017.” [In Russian.] http://www.customs.ru/index2. php?option=com_content $\&$ view $=$ article $\& i d=25396:-2017-\&$ catid $=52: 2011-01-24-16-$ 28-57\&Itemid=1978 (accessed October 31, 2018).

Fuglie, Keith O. 2004. "Challenging Bennet's Law: The New Economies of Starchy Staples in Asia." Food Policy 29 (2): 187-202.

Grain. 2008. "Introducción A La Crisis Alimentaria Global" [Introduction to the Global Food Crisis]. October. https://www.grain.org/article/entries/4175-introduccion-a-lacrisis-alimentaria-global (accessed October 15, 2018).

Institute of Development Studies. 2008. "The Growing Demand for Livestock." ID21 Insights 72, February. https://assets.publishing.service.gov.uk/media/ 57a08b96e5274a27b2000c2f/insights72.pdf (accessed October 15, 2018).

Kotenko, Aliona. 2010. “Obespechenie prodovol'stvennoj bezopasnosti Rossii v sovremennyh uslovijah" [Ensuring Food Security of Russia in Modern Conditions]. Baltijskij ekonomicheskij zhurnal [Baltic Economic Journal] 2 (4): 139-149.

Likhacheva Anastasia, Makarov Igor, and Savelyeva Alina. 2010. "Daily Bread and Water." Russia in Global Affairs, October 15. http://eng.globalaffairs.ru/number/Daily-Breadand-Water-15003 (accessed October 15, 2018).

Maslow, Abraham H. 1943. "A Theory of Human Motivation." Psychological Review 50 (4): 370-396.

Meadows, Donella H., Dennis L. Meadows, Jørgen Randers, and William W. Behrens III. 1972. The Limits to Growth: A Report for the Club of Rome's Project on the Predicament of Mankind. New York: Universe Books.

Mishin, Valery. 2016. "Rossiya-KNDR: vzaimniy poisk putey integrazii. Vozmozhnosti I perspektivi” [Russia-North Korea: Mutual Search of Integration Paths: Possibilities 
and Prospects]. Rossiya I ATR [Russia and Asia Pacific Region] 2 (92): 62-70.

Pingalli, Prabhu. 2006. "Westernization of Asian Diets and the Transformation of Food Systems: Implications for Research and Policy." Food Policy 32 (2): 281-298.

Regmi Anita, Hiroyuki Takeshima, and Laurian Unnevehr. 2008. Convergence in Global Food Demand and Delivery. USDA Economic Research Report Number 56, March. http://ageconsearch.umn.edu/bitstream/56449/2/err56.pdf (accessed October 15, 2018).

Russian Foreign Trade. 2017. "Russian Trade Report.” Accessed November 3. http:// russian-trade.com/reports-and-reviews/2017-02/torgovlya-mezhdu-rossiey-i-kndrsevernoy-koreey-v-2016-g/.

Savelyeva, Alina V. 2014. “Rol' Latinskoy Ameriki v obespechenii mirovoy prodovol'stvennoy bezopasnosti (krugliy stol v ILA RAN)" [The Role of Latin America in Guaranteeing Global Food Security (Round Table in ILA RAC)]. Latinskaya Amerika [Latin America] 12: 31-45.

Schroeder, Ted C., Andrew P. Berkley, and Kathi C. Schroeder. 1995. "Income Growth and International Meat Consumption." Journal of International Food and Agribusiness Marketing 7 (3): 15-30.

Serova, Evgenia V. 2012. Deshevogo prodovol'stvija ne budet [There Will Be No Cheap Food]. Informacionnyj otdel Rossijskogo centra issledovanij ATJeS. [Information Department of Russian APEC-study center].

Toloraya, George D. 2014. "Russia and the Countries of the Korean Peninsula." MGIMO Review of International Relations 4 (37). http://www.vestnik.mgimo.ru/en/razdely/ international-relations/russia-and-countries-korean-peninsula (accessed October 15, 2018).

UNCTAD (United Nations Conference on Trade and Development). 2017. "UNCTADSTAT." Accessed November 1. http://unctadstat.unctad.org/wds/TableViewer/tableView. aspx?ReportId=30727.

\footnotetext{
Alina Shcherbakova (Ph.D) is an Associate Professor in the Department of World Economy at the National Research University Higher School of Economics (HSE). She graduated from the Faculty of World Economy and International Affairs (HSE, Moscow, Russia) in 2009. She is also a Head of the Iberoamerican sector at HSE, a Research Fellow in the Institute of Latin America of the Russian Academy of Sciences, and an Associate Professor at the People's Friendship University of Russia. As a researcher she works on subjects related to the global food market and its transformation, the economy of Latin America, agricultural policies of Brazil and Russia, sustainable development in BRICS countries, global governance, and economic relations between Russia and Asian countries.

Denis Shcherbakov (Ph.D.) is an Associate Professor in the School of Oriental Studies at the National Research University Higher School of Economics (HSE), and an academic supervisor at HSE-Kyung Hee University Double Degree Programme "Economics and Politics in Asia." He graduated from Moscow State University in 2005, was an exchange student in Tokai University (Japan) during 20032004 and completed his Ph.D. in 2012. Before coming to HSE Denis spent five years in The Trade Representation of the Russian Federation in Japan working as an adviser. As a researcher he works on subjects related to the economic relations between Russia and Asian countries, economy of Japan, international trade, and international organizations.
} 